\title{
Teaching students the traits that matter in Taiwan: A structured conceptualization approach
}

\author{
Chen, Yu-Li $\bowtie$ \\ Lunghwa University of Science and Technology, Taiwan, ROC (ylchen@mail.Ihu.edu.tw)
}

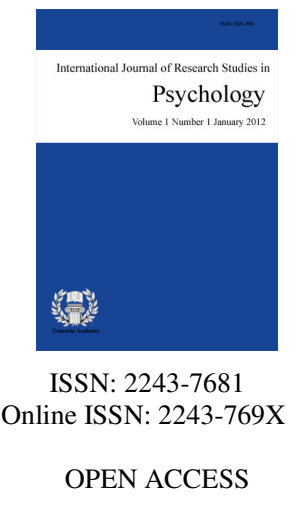

\section{Abstract}

The recent rise in the importance of fostering students' holistic development has led to various curricular changes. Universities in Taiwan have slowly transformed their general education curriculum to include the development of various competencies. However still, recent statistics have shown that universities in Taiwan, while pushing for quantity, educational quality are neglected. It is important that as Taiwan's universities transform into global institutions of learning, emphasis should be placed not only on the quantity of students, but also towards the quality of graduates. With this in mind, this paper will showcase the development and validation of a set of traits that are crucial for future Taiwanese graduates. Participants in the trait-development stage are twenty experts comprised of school administrators, educators, researchers, and industry professionals, while the validation stage consists of 398 university students. Brainstorming sessions were organized wherein ideas with regard to the important traits that teachers should impart to students were generated. The structured conceptualization method of concept mapping and a mixed-method participatory approach that combined group processes with a sequence of multivariate statistical analyses were used to summarize the complex group discussions accomplished by the participants. In addition, Confirmatory Factor Analysis was used to validate the proposed traits. Results show that future graduates need to possess six major traits, namely: study skills, life skills, utilitarianism, compassion, synergy, and global vision. Within these major traits, 20 different characteristics are also found. Implications are then given on how and why educators should focus on developing such traits.

Keywords: student attitudes; concept mapping; holistic individual; general education; global literacy 


\section{Teaching students the traits that matter in Taiwan: A structured conceptualization approach}

\section{Introduction}

Since the beginning of 2000, agencies within the United Nations (UN) together with local governments all over the world have launched four initiatives, all of which focus on education in one way or another. These are Education for All, Millennium Development Goals, the UN Literacy Decade, and the UN Decade of Education for Sustainable Development. Within such framework, universities all over the world (including Taiwan) have slowly transformed their goals to include the education of the masses. However, recent statistics show that while pushing for quantity, the quality of education has been neglected. Such a drive towards massification of higher education has actually caused the average qualification for academies in many countries to decline (Altbach, Reisberg, \& Rumbley, 2009).

In this postmodern age, economic imparity, the destruction of world ecology, war and political conflict, terrorism, destruction of distinctive cultures, social inequality, and ethnic conflict are causing distrust and malice among people, and there exists an identity crisis in the very depth of the human spirit (Noddings, 2005). Furthermore, within an economic perspective, a transnational global society has already emerged (Gutek, 1993). Such emergence has brought about drastic changes not only in our daily living, but in the behaviors, attitudes, and values of the people. In reality, there is indeed a need to not only revisit, but rethink the humanitarian values in this globalized society. Hence, the cultivation of a holistic individual should be able to rekindle the innate goodness of humanity.

In Taiwan, statistics show that university acceptance rates have reached an all-time high of $99 \%$ due to the transformation age from elite education to mass education. Over the past two decades, the numbers of higher education institutions in Taiwan have undergone phenomenal growth (from 29 universities and colleges in 1986 to 160 institutions in 2012) (Ministry of Education in Taiwan, 2012). Competition among institutions for recruiting students and earning notable reputations has been keen. Most universities and colleges endeavored to develop exclusive characteristics for academic excellence, university positioning, and survival over the long run. Taiwan Ministry of Education has provided funding for schools to enhance quality of education; therefore college and universities have actively sought funding and applied grants from the government such as Teaching Excellence Project and Paradigm Technology-based University Project. Moreover, globalization and technological advances have resulted in the internationalization of higher education institutions (Altbach, 2005; Mok, 2006). In recent years, there has been a growing recognition of the importance of cultivating the international mobility of talent of students due to globalization (D'Costa, 2008; Kuznetsov \& Sabel, 2008; Solimano, 2006, 2008). It is important that as Taiwan's universities transform into global institutions of learning, emphasis should be placed not only on the quantity of students, but also towards the quality of future graduates. With the notion that quality education includes the development of a holistic individual, developing the traits that need fostering in a holistic individual is therefore necessary.

It is noted that to develop a holistic individual, universities must be able to instill in their students the necessary skills needed earlier and more preferably within the general education curriculum as this shall be able to prompt the educators and administrators to rethink the curriculum needed in preparing students as future citizens. In light of this, the primary objective of this study is to determine a set of traits that are crucial for future Taiwanese graduates. The next section will go over the various distinct features of a holistic individual. Then a detailed outline of the research methodology will be presented, followed by the discussion of the results. Lastly, a concluding section will summarize the implications of the various findings. 
1.1 Research questions:

$>\quad$ What are the traits that are crucial for future Taiwanese graduates?

$>\quad$ How important the traits are and how feasible to develop these traits?

$>\quad$ Are students' opinions different from the traits generated by school administrators, educators, researchers, and industry professionals?

\section{Theoretical framework}

\subsection{Holistic individual}

The holistic individual is quite a complex concept, wherein there is not one standalone definition (Forbes, 1996; Hent.org, 2011a). Simply put, holistic is defined as relating to or concerned with the whole (overall) (Holistic, 2012). In a school setting, holistic education is the overall education that an individual needs. Holistic Education is also said to be a multi-leveled experiential journey of discovery, expression, and mastery where all students and teachers learn and grow together (Hent.org, 2011b). Furthermore, Hent.org (2011) stresses that the most important aspect of holistic education is the relationships that exist within and between learners and their environment, while empowering learners to live fully in the present and to co-create preferred futures.

The concept of holistic education, as proposed in this study, advocates the notion of global literacy. This study anchors the much needed basic attitudes, skills, and traits that an individual should possess in the current and future age. Banks (2000) mentioned that global literacy is a form of re-conceptualized citizenship and a sort of multi-cultural citizenship, which enables students to acquire a delicate balance of cultural, national, and global identification. Nakamura (2002) emphasizes that global literacy should include cross-cultural competence, a sense of sensitivity in multi-cultural, trans-cultural, and trans-national perspectives. Furthermore, it should also help develop cognitive, affective, and social skills to reconcile from one's own strength and integrate seemingly the opposing values on a higher level for the purpose of equitable coexistence within society (Nakamura, 2002).

Holistic education is also seen as an offspring of the current push for global education. A seminal literature written by Fisher and Hicks (1985) states that global education promotes the knowledge, attitudes, and skills relevant to living responsibly in a multicultural and interdependent world. Within the holistic education classroom, a class is often seen as a community, which is within a larger community of the school. And a class itself is within the larger community of the village, town, or city, and by extension, within the larger community of humanity (Krishnamurti, 1955, 1978). In sum, holistic education does not exist in a single and consistent form (Forbes, 1996). It is best described as "a group of beliefs, feelings, principles, and general ideas that share a family resemblance" (Forbes, 2003, p. 2).

Ultimately, holistic education focuses on the fullest possible development of a person, encouraging individuals to become the best they can be and enabling them to experience much more from life in pursuit of their goals (Forbes, 2003, p. 17). In essence, as the world evolves and changes occur, an educational perspective arises from contemporary people living and interacting in an increasingly globalized world, which is crucial to achieve a consistently improved education. It gives learners the opportunity and competences to reflect and share their own point-of-view in an expanded and inter-connected society, as well as an ability to understand and discuss complex relationships between common social and ecological issues.

\subsection{Taiwan General Education}

It has been over 25 years since the Taiwan Ministry of Education (MOE) issued the Implementation Measure for University General Education in 1984, and for Taiwan higher education institutions to implement general education. Before this, some general courses such as Chinese and History were offered as common 
courses in most colleges and universities but only National Taiwan University and Tunghai University offered general education courses (Shih, 2010). Proportionately, around a quarter of the total required graduation credits, which normally range from 128 to 148 , are general education courses. This indicates an emphasis on general education. However, not much attention or concern was given in many schools and funding was not sufficiently provided in the beginning of its implementation. Up to now, most Taiwanese students pursue professional knowledge in higher education and get a degree or certificate with an emphasis on their careers, yet ignore the necessary literacy that they should be equipped with in a multicultural society (Liu, 2007). In response to the challenge of the future, there's recently been a growing recognition in the importance of the role which general education plays in an era of rapid change in society and how general education can develop a healthy and holistic individual (Shih, 2010).

General education includes in its definition: basic education, liberal education, and quality education or education for all-round development. In Taiwan's higher education institutions, it covers a wide range of required courses such as Chinese literature, foreign language, physical education, and service learning. In terms of liberal education, it covers areas in literature and arts, historical thinking, world civilization, philosophy and moral reasoning, civic awareness, life science and so on. The MOE directive requires universities to offer a variety of electives in seven areas including literature and art, history and culture, social and philosophy, mathematics and logic, physical sciences, life sciences, and applied science and technology. These courses are designed to introduce "a dialogue of diversity and integration among different academic disciplines and new and old ways of thinking, and especially to increase student cultural literacy while the country embraces globalization and localization in a lifelong learning society" (Chou \& Ching, 2012, pp. 173-174).

\section{Methodology}

The current study is separated into two stages. The first stage is to utilize the qualitative process of a structured conceptualization method of concept mapping to develop the traits students need. The second stage is to validate the traits through a quantitative survey administered to selected university students. A structured conceptualization method can be used as both a descriptive and interpretive tool for understanding results (Caracelli, 2002). Concept mapping is a type of structured conceptualization which can be used by groups to develop a conceptual framework which can guide evaluation or planning (Kane \& Trochim, 2007; Trochim, 1989b; Trochim \& Kane, 2005). Concept mapping is also said to be a useful alternative for analyzing open-ended responses (Jackson \& Trochim, 2002), wherein opinions from various stakeholders are being assessed and solutions generated in all types of fields (Leonard \& Ashley, 2012; van Manen et al., 2012).

For the present study, the main objective is to develop and validate a set of traits inherent in Taiwan general education that can appropriately define a holistic individual. In order to accomplish such a difficult task, it is essential to both work across a wide variety of disciplines and include a diverse collaboration of stakeholders at all levels of the academic system as well as the professionals in the field (non-academic), school administrators, policymakers, and the academic research community. These challenges place considerable burdens on the academic system and require processes and methods that can address the complexity and the demanding requirements of such work. Therefore, to address the challenges of this nature, educational policy researchers have over the past three decades developed a methodology called structured conceptualization (Trochim \& Linton, 1986).

The term 'structured conceptualization' refers to any process which can be described as a sequence of concrete operationally-defined steps and which yields a conceptual representation (Trochim \& Linton, 1986). In the typical case, six steps are involved: the Preparation (including selection of participants and development of focus for the conceptualization); the Generation of statements; the Structuring of statements; the Representation of statements in the form of a concept map (using multidimensional scaling and cluster analysis); the Interpretation of maps; and, the Utilization of maps. In essence, concept mapping encourages the group to stay on task and resolve relatively quickly an interpretable conceptual framework, while yielding a graphical or 
Teaching students the traits that matter in Taiwan: A structured conceptualization approach

pictorial product which simultaneously shows all major ideas and their interrelationships.

\subsection{Preparation}

During the preparation step, the focus for the concept mapping was operationalized; participants were selected, and a schedule was developed. Two major tasks were undertaken prior to the commencement of the actual group process. First, the researcher decided on who would participate in the process. Second, the researcher then worked with the participants to decide on the specific focus for the conceptualization. In essence, the researcher's role was only to manage the process, while the content, interpretation, and utilization of the concept map were determined entirely by the group.

In the scenario within which concept mapping is applied, it is assumed that there is an identifiable group responsible for guiding the evaluation or planning effort. Assignment of the right participants are critical to the success and accuracy of the entire process (Drew, Hardman, \& Hosp, 2008). Scholars mentioned that errors during this phase plague investigators in many disciplines and can easily corrupt the worth of the entire study (Creswell, 2005; Flick, Steinke, \& Kardoff, 2004). For the current study, participants are twenty strategically-selected participants which comprises of 10 scholars, 5 school administrators, and the remaining 5 professionals from the industry. In most concept mapping studies sample sizes between 10 to 20 participants seems adequate (Trochim, 1989b; Trochim \& Kane, 2005), as long as the participants have a justifiable role in the discussion. It is further noted that a group size of 20 insures a variety of opinions and still enables good group discussion and interpretation (Trochim, 1989b).

\section{Table 1}

Participants' demography

\begin{tabular}{llll}
\hline Items & & $N$ & Percentage \\
\hline Gender & Male & 12 & 60 \\
& Female & 8 & 40 \\
\hline Age & $26-40$ & 6 & 30 \\
& $41-60$ & 13 & 65 \\
& Above 60 & 1 & 5 \\
\hline Field & Academic & \\
& Teaching & 10 & 50 \\
& Administrative & 5 & 25 \\
& Industry & \\
& Chief Executive & 2 & 10 \\
& Managerial & 3 & 15 \\
\hline Experience (years) & Less than 10 & 5 & 25 \\
& 10-20 & 10 & 50 \\
& Above 20 & 5 & 25 \\
\hline Region & Northern & 10 & 67 \\
& Middle and Southern & 5 & 33 \\
\hline
\end{tabular}

Table 1 shows the background demography of the twenty participants. From the figures depicted within the table, 15 participants are from academies with 8 from comprehensive universities ( 5 teaching/3 administration) and 7 from technology-based universities (5 teaching/2 administration). These participants are from different fields including Humanities and Arts, Business, Engineering, Social Sciences, Medical Science, Mathematical, Physical and Life Science. Roughly 70 out of the 160 Taiwanese universities and colleges are located in the northern part. There is high homogeneity of higher education in Taiwan (Academia Sinica, 2013). So 10 (67\%) among them are from Northern Taiwan whereas 5 (33\%) are from the Middle and Southern Taiwan. Besides, one worth mentioning is the five professionals coming from the industry section. Within the five, two participants are currently the Chief Executive Officers of two major corporations in Taiwan, while the remaining three are top level managers in the Tourism and Business industry. Experts from these sectors of the industry are deliberately selected due to the fact that the Tourism and Business industries are the two most promising areas of 
development, (Kuo, 2012; C.-K. Wang, 2013); wherein job employment opportunities are in high demand (A. Wang, 2013). As for the participants representing the academe (teaching and administrative), all of the participants have taught in the general education program; while most of them have participated in the curricular reforms in their respected universities. Furthermore, the participants' average years of experience are around 15.5 years. Such rich background is needed to ensure the validity of the results gathered.

\subsection{Reliability}

With regard to the reliability of the concept mapping process, various methods have been proposed (Trochim, 1993), however it is customary to report the average bridging values of the clusters as a way of presenting the reliability of the sorts (Jackson \& Trochim, 2002). Table 2 shows the various average bridging values of the dimensions ranging from 0.19 to 0.44 . Cluster bridging values actually indicate how cohesive the statements are with the other statements around them; hence statements that are difficult to sort will show up as having a high bridging value (Concept System, 1996). In other words, lower bridging values are better indicators of the meanings which are sorted into (Concept System, 2013).

Table 2

Bridging values of the 6 dimensions

\begin{tabular}{lllll}
\hline \multicolumn{1}{c}{ Dimension } & \multicolumn{1}{c}{ SD } & \multicolumn{1}{c}{ Min } & \multicolumn{1}{c}{ Max } & \multicolumn{1}{c}{ Mean } \\
\hline Synergy & 0.21 & 0.20 & 1.00 & 0.40 \\
Study skills & 0.08 & 0.12 & 0.43 & 0.24 \\
Life skills & 0.16 & 0.26 & 0.83 & 0.47 \\
Compassion & 0.14 & 0.13 & 0.71 & 0.37 \\
Utilitarianism & 0.13 & 0.00 & 0.39 & 0.19 \\
Global vision & 0.19 & 0.09 & 0.84 & 0.44 \\
\hline
\end{tabular}

\subsection{Generation}

Within the generation of the statement stage (similar to a brainstorming session), participants were first contacted and informed on the date and venue of the meeting session. Within the meeting, participants were then asked to generate ideas pertinent to the topic of interest. In other words, participants were asked to provide statements describing 'what traits future Taiwan graduates should possess' in order to succeed in society. Participants were encouraged to generate as many statements as possible and were told that there should be no criticism or discussion regarding the legitimacy of the statements which were generated during the session. Participants were encouraged to ask for clarification of any unfamiliar terms or jargon so that all who participated understood what would be intended by a given statement.

Once a final set of statements had been generated, the group re-examined the statements for editing considerations as sometimes the wording of statements generated in a brainstorming session was awkward or a technical jargon was not clear. In general, each statement should be consistent with what would be called for in the brainstorming prompt and should be detailed enough so that every member of the group could understand the essential meaning of the statement. After going through all the statements, the group finally agreed with the final set of 90 statements describing the future graduates. Before the session ended, each of the participants was given a set of cards wherein each of the statements was printed on. In addition, a 10-point Likert type survey was provided, wherein the participants were asked to rank each statement for their importance for the student and their feasibility of being accomplished within the school.

\subsection{Structuring}

Concept mapping analysis encompasses the organization and representation phases wherein the core data for 
Teaching students the traits that matter in Taiwan: A structured conceptualization approach

a concept map comes from unstructured or free sort or also known as the structuring of the statement procedures (Coxon, 1999; Weller \& Romney, 1988). During this stage, participants were tasked to group the generated statements into piles of similar ones. Participants were free to use as few or as many piles as they thought necessary to arrange the statement set meaningfully in terms of their similarity. Participants were also told that a single statement did not constitute a pile, nor placing all of the statements into one pile was allowed. After the piles were finalized, participants were asked to provide a name and their corresponding description to each pile. The piles and the Likert type survey were then collected from all the participants in order to proceed to the data analysis phase.

\subsection{Representation}

Representation of the statement phase is actually the data analysis stage of the concept mapping method. The statements are data that are decidedly judgmental and qualitative. To use the data in the subsequent quantitative multivariate analyses, each sort was first converted to a 0 and 1 co-occurrence matrix (Coxon, 1999), which had as many rows and columns as there were statements. A 1 was entered into a cell if the row and column statement pair was placed by the participant in the same pile and a 0 was entered if the statements were not sorted together in a pile. These matrices were then summed across all participants, yielding a similarity matrix that indicated the number of participants that sorted each pair of statements together. This summed square similarity matrix is the input for multidimensional scaling (MDS) analysis (Davison, 1983; Kruskal \& Wish, 1978), which takes dissimilarity data and represents them as distances in Euclidean space.

\subsection{Interpretation and utilization}

Within concept mapping, the MDS solution is typically restricted to two dimensions to allow for the integration of additional information from cluster and rating analyses. Thus, for each statement, the MDS analysis yielded an $\mathrm{X}$ and a $\mathrm{Y}$ value. When plotted in a bi-variate plot, these constituted the basic point map form of the concept map. The MDS X,Y values were the inputs for hierarchical cluster analysis using Ward's algorithm (Anderberg, 1973; Everitt, 1980), which had the effect of partitioning the MDS statement map hierarchically into non-overlapping clusters. This cluster arrangement was then superimposed on the point map (the cluster map) forming meaningful patterns, thus, depicting the different traits future Taiwan graduates should possess.

\section{Results and discussions}

\subsection{Stage one-trait development}

During the representation stage, the MDS takes use of the information from the sorting activity to locate each item as a separate point on a two-dimensional map. In order to do this, data gathered from the sorting activity were entered into the Concept System, a computer program which facilitates the entry and analysis of data developed by Trochim (1989a), which uses a combination of multidimensional scaling and cluster analysis techniques to represent graphically the conceptual relationships underlying the data. The two-dimensional map is known as a Point Map (please see Figure 1). Statements (points) that were close together on this map were statements that generally were sorted together more often than statements (points) that were not geographically close together.

The interpretation phase grouped individual statements on the map into clusters, reflecting the different types of traits. The points on the map were grouped using Ward's hierarchical cluster analysis (Anderberg, 1973; Everitt, 1980) on the X - Y coordinate provided by the MDS. After examining a variety of different number of cluster solutions, a solution consisting of 20 clusters (sub-traits) was determined to be best. Furthermore, these 20 clusters could be further grouped into 6 major clusters (major traits). This diagram of clusters is known as the Cluster Map (please see Figures 2 and 3). 


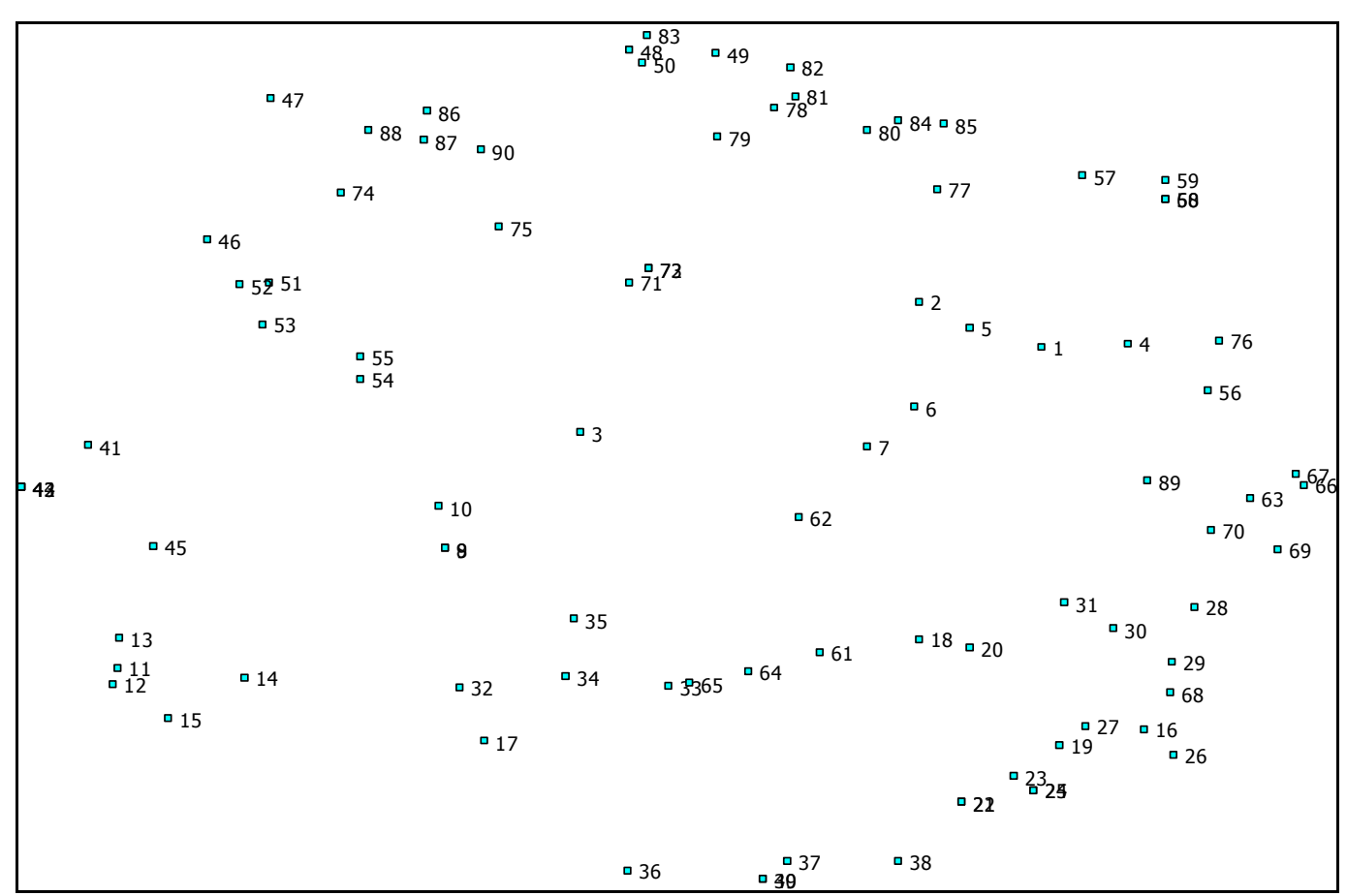

Figure 1. Point map

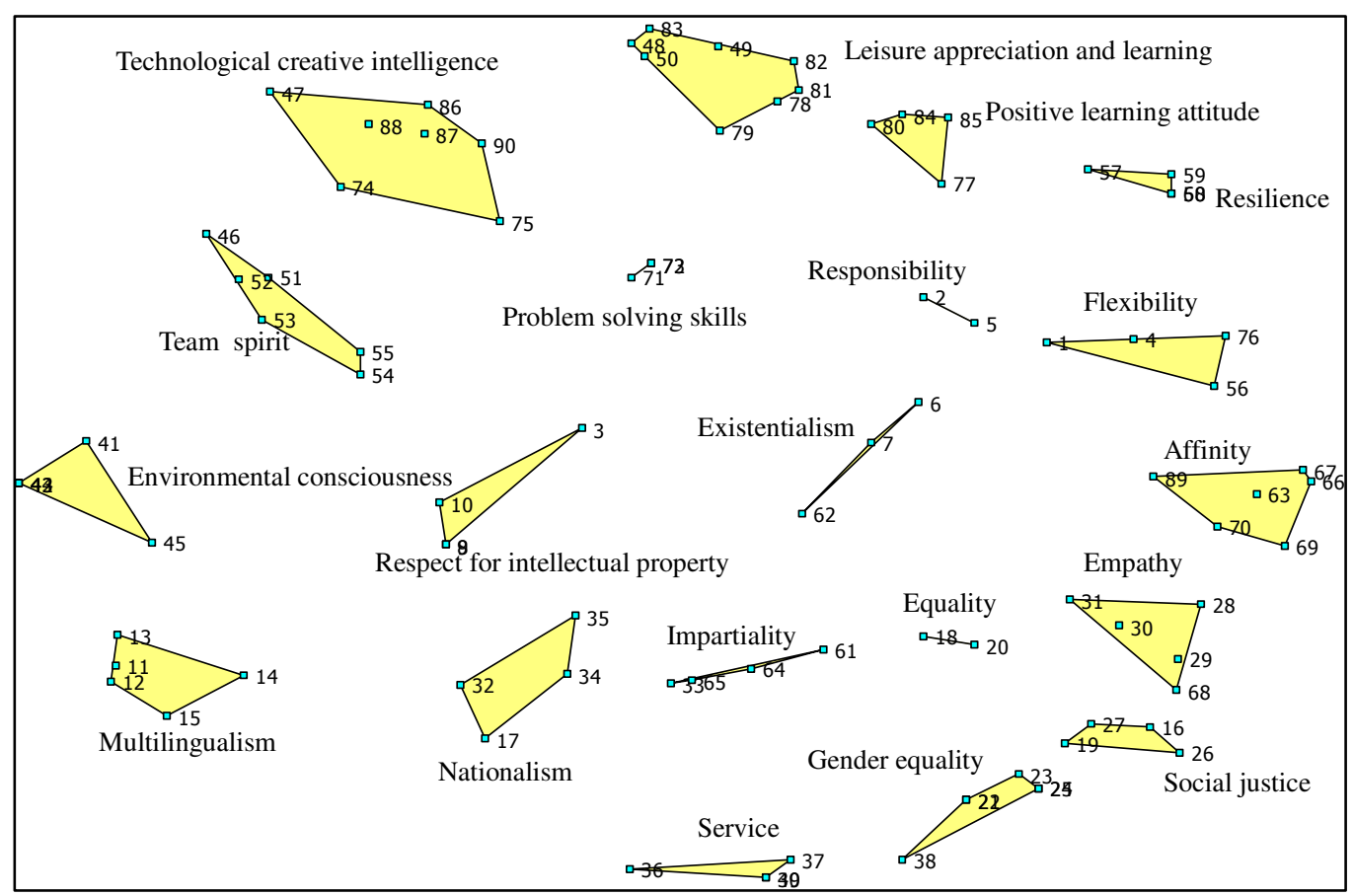

Figure 2. Point-cluster map (20 sub-traits)

Within the point-cluster map, statements were displayed exactly in which specific clusters they were grouped with. These clusters represent the 20 characteristics or sub-traits that are crucial for the development of Taiwan college students. The 20 sub-traits are as follows: technological creative intelligence, problem solving skills, team spirit, leisure appreciation and learning, positive learning attitude, flexibility, resilience, responsibility, existentialism, affinity, empathy, social justice, equality, impartiality, gender equality, service, environmental consciousness, respect for intellectual property, multilingualism, and nationalism. Furthermore, Figure 3 further displays the 6 major traits, namely: synergy, study skills, life skills, compassion, utilitarianism, 
and global vision, wherein the 20 sub-traits belong to.

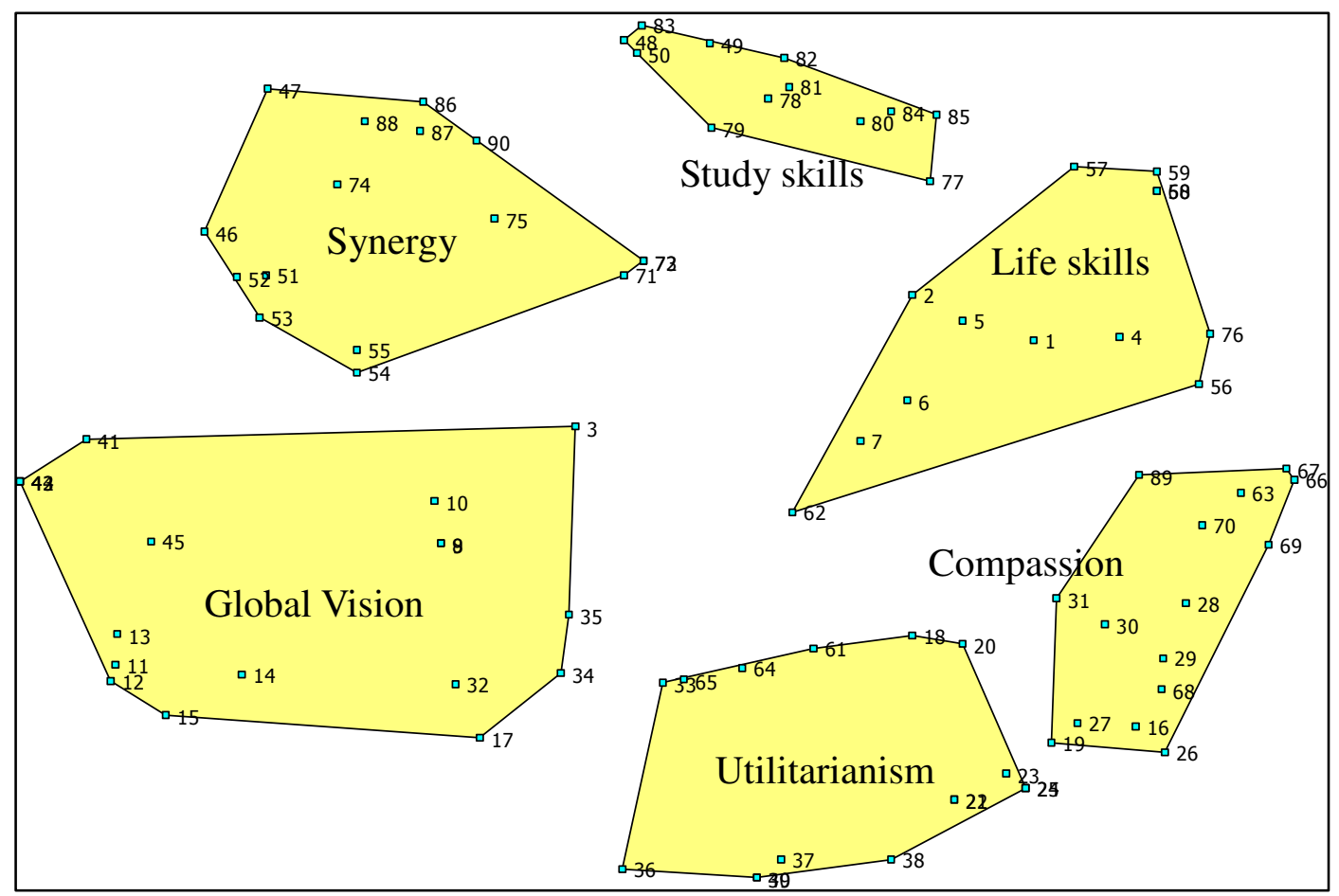

Figure 3. Point-cluster map (6 major traits)

Research question 1: What are the traits that are crucial for future Taiwanese graduates?

The 6 major traits are study skills, synergy, global vision, utilitarianism, compassion, and life skills wherein the 20 sub-traits belong to. Each of the major traits will be depicted as follows.

Study skills are composed of two traits namely: leisure appreciation and learning, positive learning attitude. Leisure appreciation and learning is the concept wherein a person knows when to relax and when to work hard. Studies have shown that adequate leisure activity can not only alleviate school related stress (Misra \& McKean, 2000), but also motivate learning (Blumenfeld et al., 1991). In a way, leisure learning is related to the concept of in-school extra and/or co-curricular activities. In Singapore, co-curricular activities are sanctioned by their Ministry of Education, because such activities are believed to be a means of enhancing the students' social interaction, leadership, healthy recreation, self-discipline, and self-confidence (Teo, 2000). Such co-curricular activities are also noted in the concept of student engagement, which has proven to be a factor in the persistent improvement of students (Hu, Ching, \& Chao, 2012; Kuh, 2009). In addition, the sub-trait positive learning attitude includes the notion of good learning habits; more importantly, a person who is both capable and motivated to learn.

Synergy is made up of the following sub-traits, namely: technological creative intelligence, problem solving skills, and team spirit. As previously mentioned, being a team player is very important. Employers are looking for people who work well with others, possess team spirit, and who have problem solving skills (Baharun, Suleiman, \& Awang, 2012). Furthermore, modern technology has been changing the way people learn, play, socialize and participate in civic life across a variety of social contexts. This new content of literacy is a term originally coined by the New London Group (Cope \& Kalantzis, 2000; New London Group, 1996). Mills (2010) called the change of practice 'digital turn' as enormous and growing attention is being paid to the new literacy practices as a result of globalization and the increasing range of technology for learning. Hence, being capable to 
perform effectively in such an environment is crucial in the future workplace.

Global vision is comprised of environmental consciousness, respect for intellectual property, multilingualism, and nationalism. The recent forms of globalization are characterized by new technology, transnational economic and trade relationships, and the diminishing nature of nation state boundaries (Canagarajah, 2006). Klein (2007) pointed out that the trend for using various languages for communication is growing. In 2009, World Economic Forum (WEF) Global Competitive Index (GCI) included primary education as one of the criteria and the 2009 World Competitiveness Yearbook issued by IMD Business School in Switzerland even included language skills in primary education and as one of the criteria for world competence (Global English Association in Taiwan, 2010). Hence, many countries have changed their policy of foreign language learning to include English and other major languages.

In addition, the awareness of the global environment is essential to educating a global individual (Shobeiri, Omidvar, \& Prahallada, 2007), because many global issues are related to the environment such as climatic change, food security, poverty, waste management, green consumerism, deforestation, land degradation, loss of biodiversity and exhaustion of natural resources (Tibury, Stevenson, Fien, \& Schreuder, 2002; UNESCO, 1992). Environmental consciousness means 'attitude towards the environment' and 'willingness to behave in an environment-friendly manner'. This attitude refers to consideration of environment preservation, recognition of existing environmental problems and the importance of solving them (The Dutch National Institute for Education Measurement, 1994). In essence, environmental issues are inter-related with economic, social, and political ones. This interdependence implies that people should respect and care for nature (Palmer, 2003) as there has been increasing deterioration of the global environment (e.g., Emanuel, 2005).

The concept of intellectual property is also important. Currently, access to information is very simple with just a few mouse clicks away. Students should learn the value of intellectual property and be careful cutting and pasting information directly from the Internet (Renard, 1999; Roth, 1999). Furthermore, students should also know how to appreciate distinct local cultures. In essence, having a global vision does not only mean to focus on globalization and internationalization, but people should also recognize the value of distinct local cultures and heritage.

Utilitarianism is composed of equality, impartiality, gender equality, and service. Equality, being impartial, and having a sense of gender equality, are all basic conditions that a college student should have to become successful (Kuh, Kinzie, Schuh, \& Whitt, 2005; Saltmarsh \& Zlotkowski, 2011). Such a general concept of utilitarianism is quite similar to the notion of civic engagement. Civic engagement is defined as working to make a difference in the civic life of our communities and developing the combination of knowledge, skills, values and motivation to make that difference. It means "promoting the quality of life in a community, through both political and non-political processes" (Ehrlich, 2000, p. vi). Furthermore, civic engagement can take many forms, from individual voluntarism to organizational involvement, to electoral participation. It includes effort to directly address an issue, work with others in a community to solve a problem or interact with the institutions of representative democracy (Carpini, 2012).

With regard to service-learning, the most widely accepted definition of service learning (Reinke, 2003) is " $a$ form of experiential education in which students engage in activities that address human and community needs together with structured opportunities intentionally designed to promote student learning and development. Reflection and reciprocity are key concepts of service-learning (Jacoby, 1996, p.5)". Haines (2010) argues that opportunities should be provided for students to interact with people and agencies outside the classroom so that a more global perspective of their studies will be developed and scientifically literate world citizens can be possibly produced when more courses integrate service-learning approach. The motivations for service learning are various: psychological reward/value expression (Katz \& Kahn, 1978), self-serving reason (Frisch \& Gerrard, 1981; King, 1984; Steiner, 1984), and altruistic reason (Frisch \& Gerrard, 1981; Hettman \& Jenkins, 1990, 2005). 
Teaching students the traits that matter in Taiwan: A structured conceptualization approach

Compassion is made up of affinity, empathy, and social justice. Besides being flexible, an individual needs to be able to express emotion and show compassion for others (Vera \& Speight, 2003). Affinity and empathy are some of the traits that students should be learning (Bok, 2006). Furthermore, empathy is said to have value adding features for students. It allows students to create bonds of trust; gives them insights into what others may be feeling or thinking; and helps them understand how or why others are reacting to situations (Martinuzzi, 2006).

Life skills are composed of flexibility, resilience, responsibility, and existentialism. To become globally competitive, today's students must possess the skills to interact with people who are different from themselves. With both the current student population and workforce being so culturally diverse, it is critical that there is an understanding and appreciation of the cultural diversity. Although the conceptualization of cross-cultural competence is rather specific, ultimately, cross-cultural competencies are traits expected to lead individuals to perform certain behaviors; wherein these behaviors are then in turn expected to lead the desired outcomes that define the effectiveness of the purpose it was designed for (Ross \& Thornson, 2008). Hence, the need of students to become flexible is a must among future graduates.

In addition, recent studies have shown that there is an increase in the occurrence of academic dishonesty in college students (Hung, 2007). However, some reported that such dishonesty is probably caused by the pressure incurred from the need to have a higher grade and college degree (Bauer, 2007), while some students inadvertently or unintentionally commit academic dishonesty due to the lack of proper guidelines and policies (McGowan, 2005). More importantly, social responsibility is highly related to being resilient and honest (O'Neill, 2011). The concern that lack of integrity and academic dishonesty while studying leads to future unethical behaviors in the workplace. In addition, the notion of academic dishonesty behaviors while in school is slightly related to impulsiveness and self-efficacy (Angell, 2006). It is therefore imperative that an early intervention on the causes of students' academic dishonesty should be accomplished in order to prevent what Nonis and Swift (2001) postulated that students who engaged in dishonest behavior in their college classes were more likely to engage in dishonest behavior on the job. Hence, students need to be trained on how to become both resilient and responsible individuals.

Research question 2: How important the traits are and how feasible to develop these traits?

To determine how important the traits are and how feasible to develop such traits within the school, a 10-point Likert type survey was given to the participants during the concept map generation stage. Table 3 shows the various mean scores of all the major and sub-traits. Among the 6 major traits, study skills is ranked as the most important trait group with a mean score of 8.32, while utilitarianism, the notion of valuing others for the greater good, is the most feasible to achieve with a mean score 6.07. Furthermore, the three most important characteristics (sub-traits) are environmental consciousness with a mean score of 9.27, followed by problem solving skills with a mean score of 8.78 , and positive learning attitude with a mean score of 8.64. In regard to the feasibility of being developed within the school, the most feasible is impartiality with a mean score of 6.54, followed by social justice with a mean score of 6.40, and equality with a mean score of 6.35 .

\section{Table 3}

Importance and feasibility of the traits

\begin{tabular}{llll}
\hline Major traits & \multicolumn{1}{c}{ Sub-traits } & Importance & Feasibility \\
\hline Synergy & & 8.48 & $\mathbf{5 . 4 6}^{\mathbf{2}}$ \\
& Technological creative intelligence & 8.42 & 5.06 \\
& Problem solving skills & 8.78 & 5.98 \\
& Team spirit & 8.41 & 5.65 \\
\hline Study skills & & $\mathbf{8 . 5 9}^{1}$ & 5.49 \\
& Leisure appreciation and learning & 8.57 & 5.16 \\
& Positive learning attitude & 8.64 & 6.15 \\
\hline
\end{tabular}


Chen, Y.-L.

Table 3 ... continued

\begin{tabular}{llll}
\hline Major traits & \multicolumn{1}{c}{ Sub-traits } & Importance & Feasibility \\
\hline Life skills & Resilience & $\mathbf{8 . 3 2}^{\mathbf{2}}$ & 5.97 \\
& Responsibility & 7.99 & 6.21 \\
& Existentialism & 8.45 & 5.50 \\
& Flexibility & 8.48 & 6.05 \\
& & 8.45 & 5.90 \\
\hline Compassion & Affinity & 8.35 & 5.88 \\
& Empathy & 8.21 & 5.35 \\
& Social justice & 8.41 & 6.10 \\
& & 8.49 & 6.40 \\
\hline Utilitarianism & Equality & 8.41 & $\mathbf{6 . 0 7}^{\mathbf{1}}$ \\
& Impartiality & 8.38 & 6.35 \\
& Gender equality & 8.63 & $\mathbf{6 . 5 4}^{\mathbf{1}}$ \\
& Service & 8.21 & 5.85 \\
& & 8.53 & 5.79 \\
\hline Global vision & Environmental consciousness & 8.44 & 5.57 \\
& Respect for intellectual property & $\mathbf{9 . 2 7 ^ { 1 }}$ & 5.54 \\
& Multilingualism & 8.48 & 6.20 \\
& Nationalism & $\mathbf{7 . 9 3}$ & 5.50 \\
& & 8.01 & $\mathbf{5 . 0 5 ^ { 2 }}$ \\
\hline
\end{tabular}

Note. ${ }^{1}$ Highest ${ }^{2}$ Lowest

To have a more visual representation of the importance and feasibility of the traits, cluster rating maps were created. The cluster rating map was created by overlaying the average rating of importance (and later feasibility) on the cluster map (please see Figures 4 and 5). Note that the layers represent the importance of the cluster. Hence, the more layers (or the higher the layers) the cluster has, the greater the importance of the cluster is.

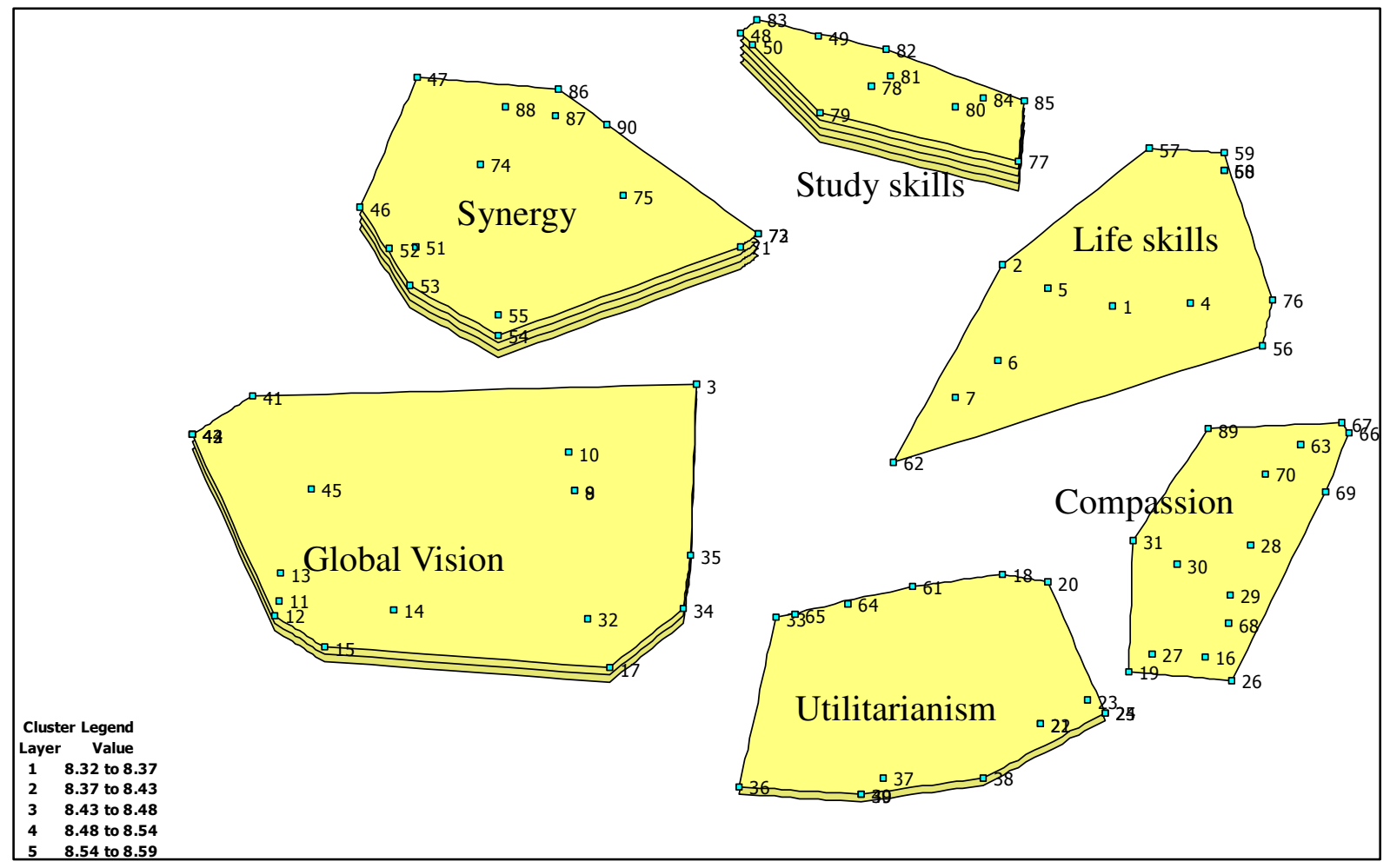

Figure 4. Cluster rating map (importance) 


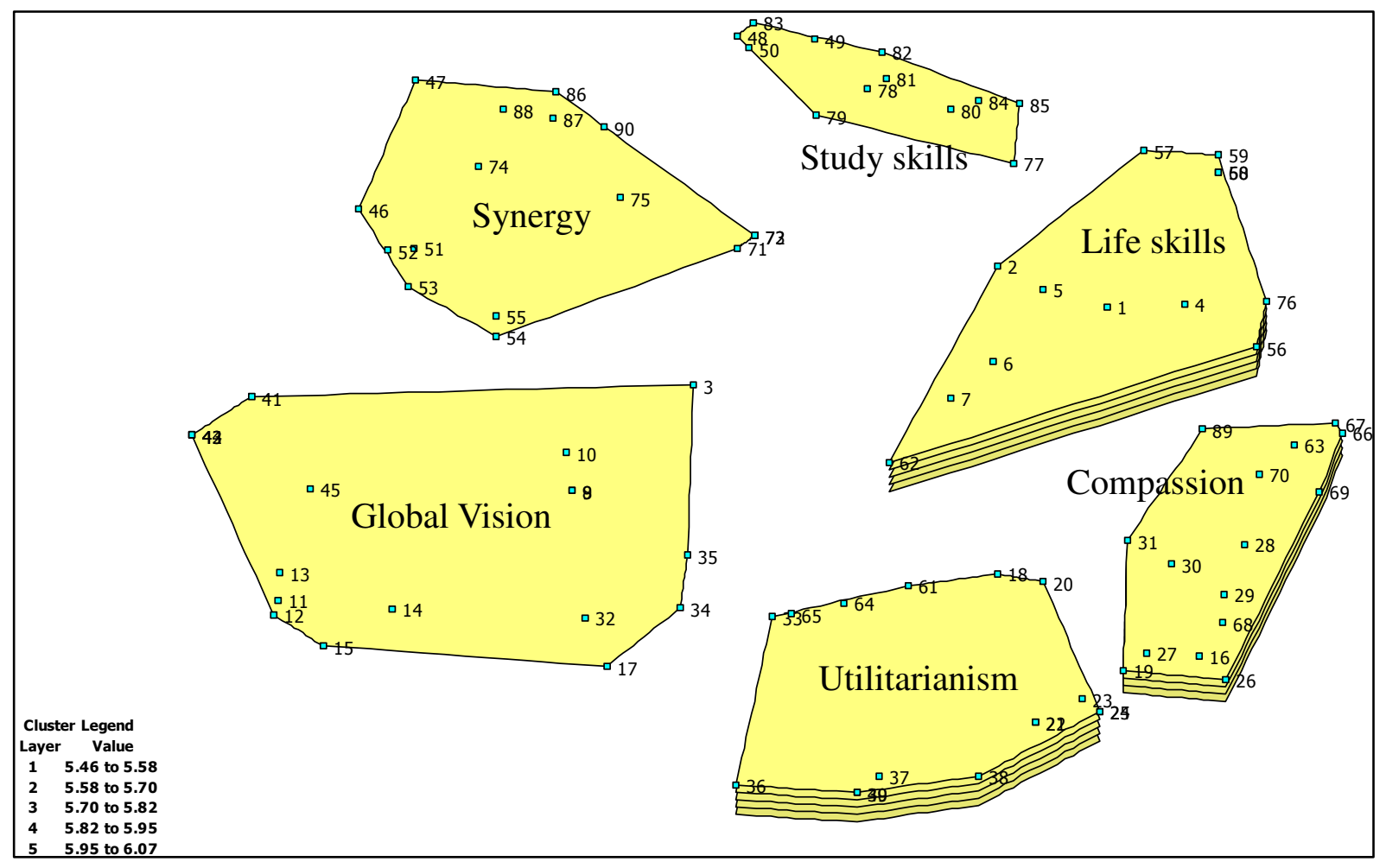

Figure 5. Cluster rating map (feasibility)

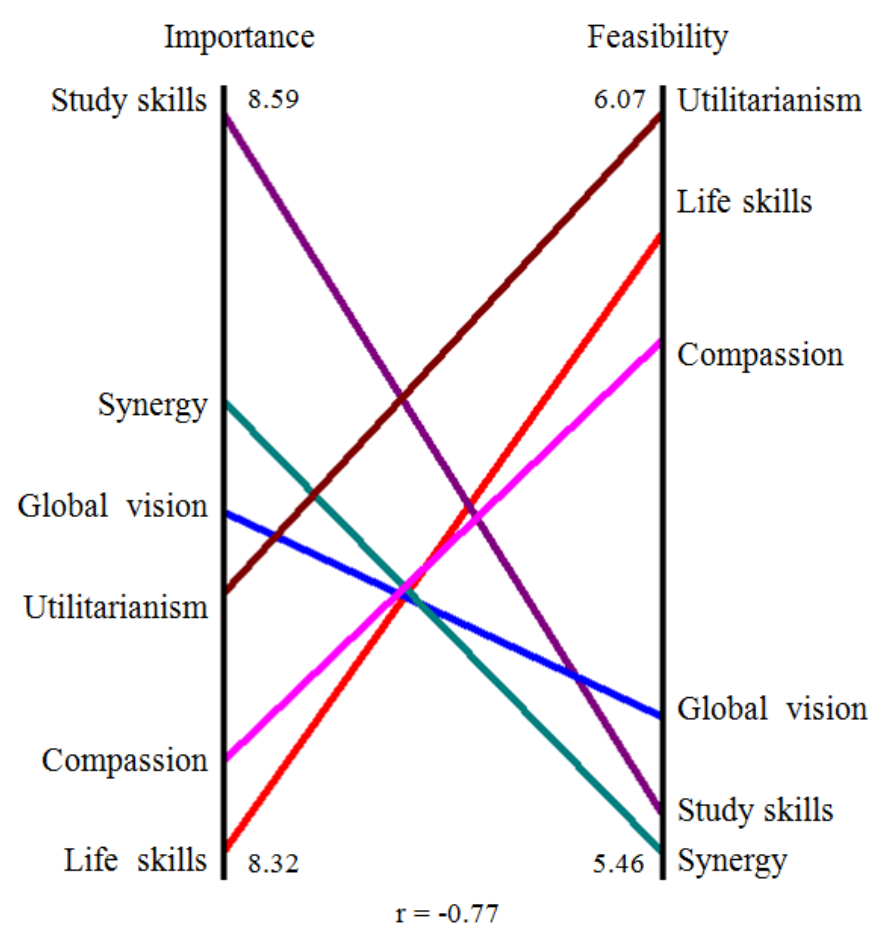

Figure 6. Pattern matching (importance versus feasibility)

Further analysis also revealed additional insight that contributed to specific recommendations for future curriculum designs. Pattern Matching (Concept System, 1996) was conducted to compare the importance ratings of clusters by various groups. Pattern Matching utilizes a ladder graph format to visually display the degree of 
agreement between the ratings of the groups being compared. If the two groups are in complete agreement, the graph would consist of a series of parallel lines and closely resemble a ladder. To the extent that the two groups are not in agreement, the lines cross and represent varying amounts of agreement/disagreement. The amount of correlation (Pearson r) between the two groups is also reported (please see Figure 6).

Figure 6 shows that there is actually a mismatch between the importance and feasibility of the major traits (Pearson correlation of $r=-0.77$ ). Besides the low mean scores of the feasibility of the traits (from 5.46 to 6.07) as compared with the importance of the traits (from 8.32 to 8.59), participants viewed study skills as the most important and almost as the least feasible to achieve. This mismatch denotes that teachers should focus more on promoting the students' positive learning attitudes and developing their appreciation of leisure and learning. In addition, results also depict that there is a need to promote the willingness and openness to cooperation (synergy) among the students. Synergy is a fairly new concept in the industry and usually means that the interaction of elements that when combined produce a total effect that is greater than the sum of the individual elements. As the need of having to work with people of different backgrounds rises in the industry, students need to learn early on how to positively interact and cooperate with people of different fields of expertise.

Further comparison of the ratings between the participants from the academy and industry shows quite interesting discrepancies. Figure 7 shows that in regard to the importance of the traits, participants from the academy and the industry seem to have various opinions (Pearson correlation of $r=-0.30$ ). However, in regard to the feasibility of the traits, both participants from the academy and industry sector agreed to some extent (Pearson correlation of $r=0.70$ ). Such results indicate that educators need to revisit the core skills that are being imparted to the students.
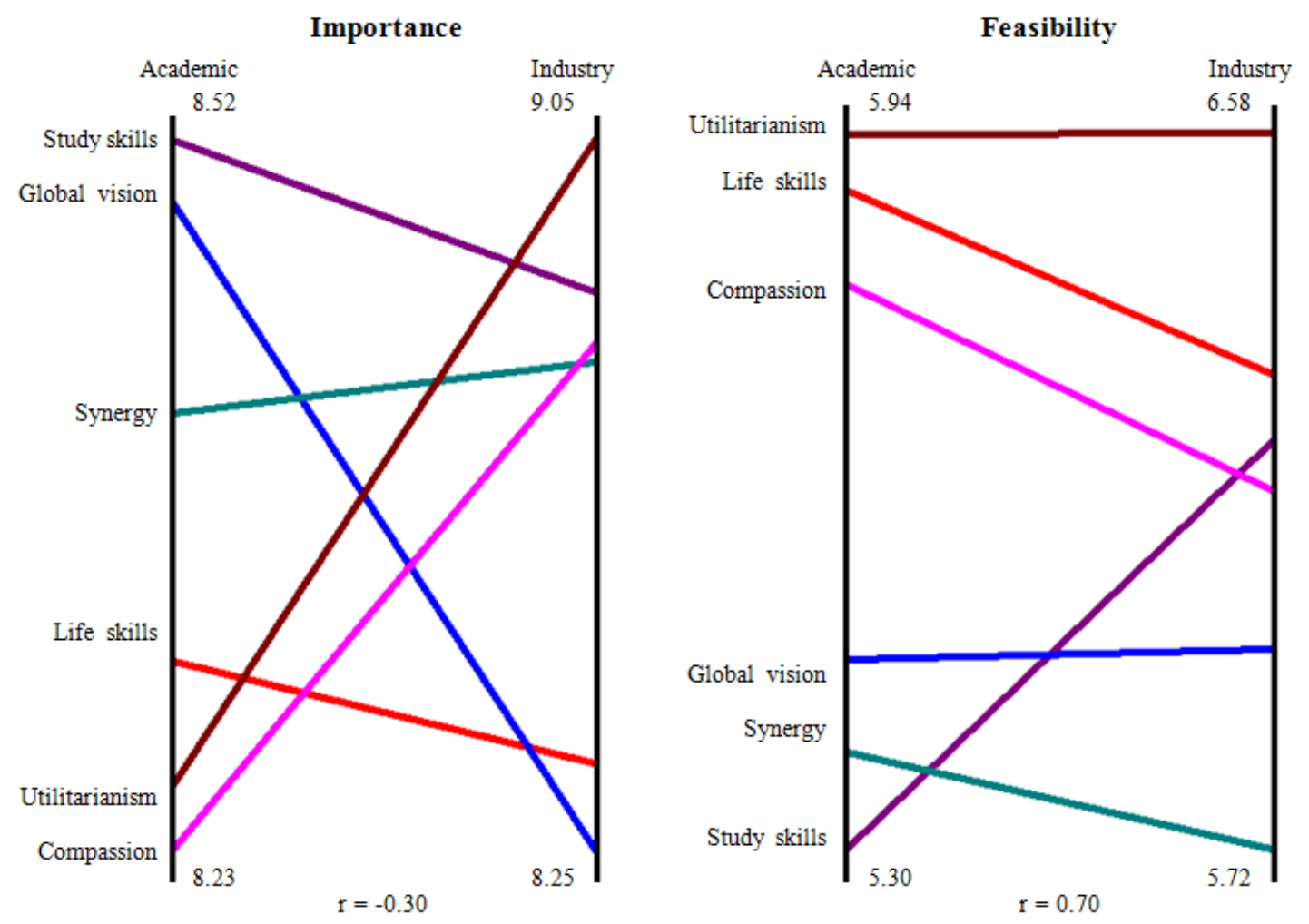

Figure 7. Pattern matching comparison between academic and industry

\subsection{Stage two - trait validation}

During the validation stage, the items generated from the concept mapping stage were designed into a survey questionnaire for students to rank their perceived importance within a 5-point Likert scale with 1 have the least importance and 5 as the most important. Students are random participants from four universities in 
Teaching students the traits that matter in Taiwan: A structured conceptualization approach

Northern Taiwan (2 national and 2 private universities). A total of 398 valid responds were collected with 191 female and 207 male students. After tabulating all the responses, confirmatory factor analysis was computed on the six major dimensions using the statistic software SPSS.

Research question 3: Are students' opinions different from the traits generated by school administrators, educators, researchers, and industry professionals?

Table 4 shows the result of the confirmatory factor analysis. Result shows that a total of 33 items were removed from the initial 90 items survey. In addition, the variance explained were also tabulated with some of the sub-traits being combined together (denoted by the sub-scripts 1 to 5), hence resulting into the computation of a common alpha reliability. Most of the factors have accepted alpha reliabilities, while only 2 fails to reach the cutoff of .60 (Impartiality with .44 and Respect for intellectual property with .52).

\section{Table 4}

Confirmatory factor analysis of the six dimensions

\begin{tabular}{|c|c|c|c|c|c|c|}
\hline Dimension & Factors (Sub-traits) & Items & Removed & Mean & Variance & Alpha \\
\hline \multirow[t]{3}{*}{$\begin{array}{l}\text { Synergy } \\
(\mathrm{M}=3.58)\end{array}$} & $\begin{array}{l}\text { Technological creative } \\
\text { intelligence }^{1}\end{array}$ & 3 & 4 & 3.55 & 27.34 & .71 \\
\hline & Problem solving skills ${ }^{1}$ & 2 & 1 & 3.76 & & \\
\hline & Team spirit & 3 & 3 & 3.42 & 23.94 & .62 \\
\hline \multirow[t]{2}{*}{$\begin{array}{l}\text { Study skills } \\
(\mathrm{M}=3.53)\end{array}$} & $\begin{array}{l}\text { Leisure appreciation and } \\
\text { learning }\end{array}$ & 7 & 1 & 3.76 & 27.52 & .80 \\
\hline & Positive learning attitude & 2 & 2 & 3.25 & 22.09 & .75 \\
\hline Life skills & Resilience $^{2}$ & 3 & 1 & 3.58 & 44.92 & .75 \\
\hline \multirow{3}{*}{$(\mathrm{M}=3.65)$} & Responsibility $^{2}$ & 1 & 1 & 3.68 & & \\
\hline & Existentialism $^{2}$ & 3 & 0 & 3.75 & & \\
\hline & Flexibility $^{2}$ & 2 & 2 & 3.53 & & \\
\hline Compassion & Affinity & 5 & 1 & 3.47 & 25.91 & .75 \\
\hline \multirow[t]{2}{*}{$(\mathrm{M}=3.51)$} & Empathy $^{3}$ & 3 & 2 & 3.65 & 22.79 & 69 \\
\hline & Social justice ${ }^{3}$ & 2 & 2 & 3.42 & & \\
\hline Utilitarianism & Equality $^{4}$ & 2 & 0 & 2.39 & 19.61 & .70 \\
\hline \multirow[t]{3}{*}{$(\mathrm{M}=3.15)$} & Gender equality $^{4}$ & 3 & 3 & 3.23 & & \\
\hline & Impartiality & 2 & 2 & 3.07 & 13.84 & .44 \\
\hline & Service & 4 & 0 & 3.90 & 22.80 & .75 \\
\hline \multirow{5}{*}{$\begin{array}{l}\text { Global vision } \\
(\mathrm{M}=3.42)\end{array}$} & Environmental consciousness $^{5}$ & 3 & 2 & 3.61 & 25.93 & .75 \\
\hline & Nationalism ${ }^{5}$ & 2 & 2 & 3.50 & & \\
\hline & Respect for intellectual property & 2 & 2 & 3.20 & 13.78 & .52 \\
\hline & Multilingualism & 3 & 2 & 3.34 & 21.61 & .78 \\
\hline & Total & 57 & 33 & & & \\
\hline
\end{tabular}

Note. Sub-traits with similar subscripts means that they can be explained by a single variance

Besides the items removed and variance explained, Table 4 also shows the mean scores of the dimensions and sub-traits. Results show that the students perceived the dimensions as the most to the least important are Life skills ( $M=3.51)$, Synergy ( $M=3.58)$, Study skills $(M=3.53)$, Compassion $(M=3.51)$, Global vision $(M=3.42)$, and Utilitarianism (M=3.15). The result is not that similar to what academic and industry experts proposed.

\section{Conclusion}

The goal of this study was to determine a set of traits that are crucial for the future Taiwanese graduates. It utilized a mixed-method participatory approach that combined group processes with a sequence of multivariate statistical analyses. A total of twenty experts comprising of school administrators, educators, researchers, and industry professionals were invited to share their ideas. What is new in this study is the utilization of the structured conceptualization method of concept mapping in providing a graphical representation of the generated ideas. More importantly, results have shown that future graduates need to develop six major traits, namely: study 
skills, life skills, utilitarianism, compassion, synergy, and global vision. Within these major traits, 20 different characteristics were also found, namely: technological creative intelligence, problem solving skills, team spirit, leisure appreciation and learning, positive learning attitude, flexibility, resilience, responsibility, existentialism, affinity, empathy, social justice, equality, impartiality, gender equality, service, environmental consciousness, respect for intellectual property, multilingualism, and nationalism. Furthermore, after validating the traits through the use of a survey questionnaire, results are not that similar to what academic and industry experts have proposed.

More importantly, there is an obvious mismatch in what is considered to be important by educators, professionals from the industry, and students. Educators agree that study skills are very important and students felt that life skills are crucial, while people from the industry believe that having a heart for the common good of everyone (utilitarianism) is better. Such results clearly indicate that educators have to reframe the current curriculum design to better include the development of the traits mentioned and strike a balance between what are perceived by the students and the need of the industry. In sum, the current study shall bring forth new ideas regarding the core developmental focus of general education in Taiwan.

Acknowledgements: This paper is sponsored by the Taiwan National Science Council (NSC 100-2410-H-262-004).

\section{References:}

Academia Sinica (2013). Higher education and technology policy proposal. Academia Sinica Report No. 9. 2013 January. Retrieved September 1, 2013 from http://www.sinica.edu.tw/advice/advice_edu2.pdf.

Altbach, P. G. (2005). Globalization and the university: Myths and realities in an unequal world. The NEA 2005 Almanac of Higher Education (pp. 63-74). Washington, DC: National Education Association.

Altbach, P. G., Reisberg, L., \& Rumbley, L. E. (2009). Trends in global higher education: Tracking an academic revolution. Paris: United Nations Educational, Scientific and Cultural Organization.

Anderberg, M. R. (1973). Cluster analysis for applications. New York: Academic Press, Inc.

Angell, L. R. (2006). The relationship of impulsiveness, personal efficacy, and academic motivation to college cheating. College Student Journal, 40(1), 118-131.

Baharun, R., Suleiman, E. S., \& Awang, Z. (2012). Changing skills required by industries: Perceptions ofwhat makes business graduates employable. African Journal of Business Management, 6(30), 8789-8796.

Banks, J. (2000). Citizenship education, diversity, and curriculum transformation. Paper presented at the Twentieth Symposium of the Intercultural Education Society, Japan.

Bauer, D. J. (2007). Root causes of academic dishonesty. Retrieved March 1, 2010, from http://www.chinapost.com.tw/commentary/the-china-post/daniel-j.-bauer/2007/07/08/116139/Root-caus es.htm

Blumenfeld, P. C., Soloway, E., Marx, R. W., Krajcik, J. S., Guzdial, M., \& Palincsar, A. (1991). Motivating project-based learning: Sustaining the doing, supporting the learning. Educational Psychologist, 26(3-4), 369-398. http://dx.doi.org/10.1080/00461520.1991.9653139

Bok, D. C. (2006). Our underachieving colleges: A candid look at how much students learn and why they should be learning more. Priceton, NJ: Princeton University Press.

Canagarajah, A. S. (2006). Negotiating the local in English as a lingua frranca. Annual Review of Applied Linguistics, 26, 197-218. http://dx.doi.org/10.1017/S0267190506000109

Caracelli, V. J. (2002). Structured conceptualization: A framework for interpreting evaluation results. Evaluation and Program Planning, 12(1), 45-52. http://dx.doi.org/10.1016/0149-7189(89)90021-9

Carpini, M. D. (2012). Civic engagement. Retrieved August 29, 2012, from http://www.apa.org/education/undergrad/civic-engagement.aspx

Chou, C. P., \& Ching, G. S. (2012). Taiwan education at the crossroad: When globalization meets localization. International and Development Education Book Series. NY: Palgrave Macmillan.

Concept System. (1996). The concept system software guide. Ithaca, NY: Concept Systems, Inc. 
Teaching students the traits that matter in Taiwan: A structured conceptualization approach

Concept System. (2013). Concept system global max software guide. Retrieved September 1, 2013, from http://www.conceptsystems.com/files/all/cs_global_max_software_guide_1.pdf

Cope, B., \& Kalantzis, M. (2000). Multicultural education: An equity framework: South Australian Department of Education Curriculum Standards and Accountability Framework.

Coxon, A. P. M. (1999). Sorting data: Collection and analysis. University papers series on quantitative applications in the social sciences no. 07-127. Thousand Oaks, CA: Sage Publications.

Creswell, J. W. (2005). Educational research: Planning, conducting, and evaluating quantitative and qualitative research (2nd ed.). Upper Saddle River, NJ: Prentice Hall.

Davison, M. L. (1983). Multidimensional scaling. New York: John Wiley \& Sons, Inc.

D'Costa, A. P. (2008). The international mobility of technical talent: trends and development implications. The international mobility of talent. Types, causes and development impact (pp. 44-83). New York.

Drew, C. J., Hardman, M. L., \& Hosp, J. L. (2008). Designing and conducting research in education. Thousand Oaks, CA: Sage Publications, Inc.

Ehrlich, T. (2000). The definition of civic engagement. Retrieved August 29, 2012, from http://www.nytimes.com/ref/college/collegespecial2/coll_aascu_defi.html

Emanuel, K. (2005). Increasing destructiveness of tropical cyclones over the past 30 years. Nature, 436(4), 686-688. http://dx.doi.org/10.1038/nature03906

Everitt, B. (1980). Cluster analysis (2nd ed.). New York: Halsted Press.

Fisher, S., \& Hicks, D. (1985). World studies 8-13: A teacher's handbook. Edinburgh: Oliver \& Boyd.

Flick, U., Steinke, I., \& Kardoff, E. v. (2004). Qualitative research: Paradigms, theories, methods, practice and contexts. Thousand Oaks, CA: Sage Publications, Inc.

Forbes, S. H. (1996). Values in holistic education. Retrieved July 15, 2012, from http://www.holistic-education.net/articles/values.pdf

Forbes, S. H. (2003). Holistic education: An analysis of its ideas and nature. Brandon, VT: Foundation for Educational Renewal.

Frisch, M. B., \& Gerrard, M. (1981). Natural helping systems: A survey of red cross volunteers. American Journal of Community Psychology, 9, 567-579. http://dx.doi.org/10.1007/BF00896477

Global English Association in Taiwan. (2010). Multilingual capability: An aid to increase individual compentency [In Chinese]. English Career, 34, 44-51.

Gutek, G. L. (1993). American education in a global society: Internationalizing teacher education. New York: Longman Publishing Group.

Haines, S. (2010). Environmental education and service learning in the tropics: Making global connections. Journal of College Science Teaching, 39(3), 16-23.

Hent.org. (2011a). What is holistic education? Retrieved July 15, 2012, from http://www.hent.org/intro1.htm

Hent.org. (2011b). What is holistic education? Part 2. Retrieved July 15, 2012, from http://www.hent.org/intro2.htm

Hettman, D. W., \& Jenkins, E. (1990, 2005). Volunteerism and social interest. Individual Psychology, 46(3), 298-304.

Holistic. (2012). Merriam-Webster.com. Retrieved July 15, 2012, from http://www.merriam-webster.com/dictionary/holistic

Hu, Y. L., Ching, G. S., \& Chao, P. C. (2012). Taiwan student engagement model: Conceptual framework and overview of psychometric properties. International Journal of Research Studies in Education, 1(1), 69-90.

Hung, J. (2007). Cheating too common in Taiwan. Retrieved March 1, 2010, from http://www.chinapost.com.tw/commentary/the-china-post/joe-hung/2007/06/25/116159/Cheating-too.ht $\underline{\mathrm{m}}$

Jackson, K. M., \& Trochim, W. M. K. (2002). Concept mapping as an alternative approach for the analysis of open-ended survey responses. Organizational Research Methods, 5(4), 307-336. http://dx.doi.org/10.1177/109442802237114

Jacoby, B. (1996). Service-learning in today's higher education. In B. Jacoby (Ed.), Service Learning in Higher education. San Francisco, CA: Jossey-Bass Publishers.

Kane, M., \& Trochim, W. M. K. (2007). Concept mapping for planning and evaluation. CA: Sage Publications.

Katz, D., \& Kahn, R. L. (1978). The social psychology of organizations (2nd ed.). New York: Wiley.

King, A. E. (1984). Volunteer participations: An analysis of the reasons people give for volunteering. Dissertation Abstracts International, 45(5), 1528-A.

Klein, C. (2007). The valuation of plurilingual competencies in an open European labour market. The International Journal of Multilingualism, 4(4), 262-281. http://dx.doi.org/10.2167/ijm075.0

Krishnamurti. (1955). Education and the significance of life. London: Victor Gollancz. 
Krishnamurti. (1978). Beginnings of learning. London: Penguin Books.

Kruskal, J. B., \& Wish, M. (1978). Multidimensional scaling. Beverly Hills, CA: Sage Publications.

Kuh, G. D. (2009). The national survey of student engagement: Conceptual and empirical foundations. New Directions for Institutional Research, 141, 5-21. http://dx.doi.org/10.1002/ir.283

Kuh, G. D., Kinzie, J., Schuh, J. H., \& Whitt, E. J. (2005). Student success in college: Creating conditions that matter. San Francisco, CA: John Wiley \& Son, Inc.

Kuo, G. (2012). Taiwan's 2011 tourism revenue hits record high. Retrieved September 1, 2013, from http://taiwantoday.tw/ct.asp?xItem=194886\&CtNode $=453$

Kuznetsov, Y., \& Sabel, C. (2008). Global mobility of talent from a perspective of new industrial policy: Open migration chains and diaspora networks. The International Mobility of Talent Types, Causes, and Development Impact, 84-113.

Leonard, H. A., \& Ashley, C. (2012). Exploring the underlying dimensions of wiolence in print advertisements. Journal of Advertising, 41(1), 77-90. http://dx.doi.org/10.2753/JOA0091-3367410106

Liu, J. Y. (2007). Present-day's general education in Taiwan's colleges and universities: Problems and solutions[In Chinese: wo guo da xue tong shi jiao yu de xian kuang 、 wen ti yu dui ce]. Journal of General Education: Theory and Practice, 1(1), 1-30.

Martinuzzi, B. (2006). What's empathy got to do with it. Retrieved August 28, 2012, from http://www.mindtools.com/pages/article/newLDR 75.htm

McGowan, U. (2005). Educational integrity: A strategic approach to anti-plagiarism. Paper presented at the Asia Pacific Educational Integrity Conference, Newcastle.

Mills, K. A. (2010). A review of the "digital turn" in the new literacy studies. Review of Educational Research, 80(2), 246-271. http://dx.doi.org/10.3102/0034654310364401

Ministry of Education in Taiwan. (2012).List of College and Universities. Ministry of Education in Taiwan. Retrieved August 26, 2013, from Ministry of Education in Taiwan Web site.

Misra, R., \& McKean, M. (2000). College students' academic stress and its relation to their anxiety, time management, and leisure satisfaction. American Journal of Health Studies, 16(1), 41-51.

Mok, K. H. (2006). Education reform and education policy in East Asia. New York, NY: Routledge.

Nakamura, K. (2002). Cultivating global literacy through English as an international language (EIL) education in Japan: A New paradigm for global education. International Education Journal, 3(5), 64-74.

New London Group. (1996). A pedagogy of multiliteracies: Designing social futures. Harvard Educational Review, 66(1), 60-92.

Noddings, N. (2005). Educating citizens for global awareness. New York and London: Teachers College Press.

Nonis, S., \& Swift, C. O. (2001). An examination of the relationship between academic dishonesty and workplace dishonesty: A multicampus investigation. Journal of Education for Business, 77(2), 69-77. http://dx.doi.org/10.1080/08832320109599052

O'Neill, N. (2011). Educating for personal and social responsibility: Levers for building collective institutional commitment. Journal of College and Character, 12(2). http://dx.doi.org/10.2202/1940-1639.1792

Palmer, J. A. (2003). Environmental education in the 21 st century: Theory, practice, progress and promise. New York: Routledge.

Reinke, S. J. (2003). Making a difference: Does service-learning promote civic engagement in MPA students? Journal of Public Affairs Education, 9(2), 129-137.

Renard, L. (1999). Cut and paste 101: Plagiarism and the net. Educational Leadership, December 1999/January 2000, 38-42.

Ross, K. G., \& Thornson, C. A. (2008). Identification of measures related to cross-cultural competence (DEOMI Internal Report No. CCC-08-2). Florida: University of Florida. Retrieved December 24, 2009 from http://www.deomi.org/CulturalReadiness/documents/Review_of_CCC_Measures_New_Cover_Page.pd f

Roth, L. (1999). Educating the cut and paste generation. Library Journal, 124(18), 42-44.

Saltmarsh, J., \& Zlotkowski, E. (2011). Higher education and democracy: Essays on service-learning and civic engagement. Philadelphia, PA: Temple University Press.

Shih, Y. H. (2010). The humanistic spirit and its implications for the general education in university [In Chinese: ren wen jing shen dui da xue tong shi jiao yu de qi shi]. Journal of Taipei Municipal University of Education, 41(2), 59-80.

Shobeiri, S. M., Omidvar, B., \& Prahallada, N. N. (2007). A comparative study of environmental awareness among secondary school students in Iran and India. International Journal of Environment, 1(1), 28-34.

Steiner, T. (1984). An investigation of motivational factors operative in prosocial volunteers. Dissertation Abstracts International, 36(6B), 3130. 
Teaching students the traits that matter in Taiwan: A structured conceptualization approach

Solimano, A. (2006). The international mobility of talent and its impact on global development: An overview (Vol. 52). United Nations Publications.

Solimano, A. (Ed.). (2008). The international mobility of talent: Types, causes, and development impact.. Oxford University Press.

Steiner, T. (1984). An investigation of motivational factors operative in prosocial volunteers. Dissertation Abstracts International, 36(6B), 3130.

Teo, C. H. (2000). Speeches. Retrieved January 11, 2010, from http://www.moe.gov.sg/media/speeches/2000/sp22012000.htm

The Dutch National Institute for Education Measurement. (1994). Environment awareness scale. from http://www.sauvez-la-terre.org/english/scale.html

Tibury, D., Stevenson, R. B., Fien, J., \& Schreuder, D. (2002). Education and sustainability: Responding to the global challenge: IUCN, Gland, Switzerland and Cambridge, UK.

Trochim, W. M. K. (1989a). The concept system. Ithaca, NY: Concept Systems.

Trochim, W. M. K. (1989b). An introduction to concept mapping for planning and evaluation. A Special Issue of Evaluation and Program Planning, 12, 1-16.

Trochim, W. M. K. (1993). Reliability of concept mapping. Paper presented at the Annual Meeting of the American Evaluation Association.

Trochim, W. M. K., \& Kane, M. (2005). Concept mapping: An introduction to structured conceptualization in health care. International Journal for Quality in Health Care, 17(3), 187-191. http://dx.doi.org/10.1093/intqhc/mzi038

Trochim, W. M. K., \& Linton, R. (1986). Conceptualization for planning and evaluation. Evaluation and Program Planning, 9, 289-308. http://dx.doi.org/10.1016/0149-7189(86)90044-3

UNESCO. (1992). United Nations Conference on Environment and Development: Agenda 21.: UNESCO, Switzerland. Retrieved from

van Manen, J. G., Kamphuis, J. H., Goossensen, A., Timman, R., Busschbach, J. J. V., \& Verheul, R. (2012). In search of patient characteristics that may guide empirically based treatment selection for personality disorder patients: Concept map approach. Journal of Personality Disorders, 26(4), 481-497. http://dx.doi.org/10.1521/pedi.2012.26.4.481

Vera, E. M., \& Speight, S. L. (2003). Multicultural competence, social justice, and counseling psychology: Expanding our roles. The Counseling Psychologist, 31(3), 253-272. http://dx.doi.org/10.1177/0011000003031003001

Wang, A. (2013). A few good guides. Retrieved September 1, 2013, from http://taiwanreview.nat.gov.tw/fp.asp?xItem=199474\&ctNode $=1446$

Wang, C.-K. (2013). About TAITRA. Retrieved September 1, 2013, from http://www.taitra.org.tw/about_01.asp

Weller, S. C., \& Romney, A. K. (1988). Systematic data collection. Newbury Park, CA: Sage Publications. 
Chen, Y.-L. 